\title{
DISTRIBUSI CHANNEL STEPNESS INDEX ZONA SESAR CIMANDIRI UNTUK IDENTIFIKASI JALUR SESAR AKTIF
}

\author{
RAHMAT INDRAJATI ${ }^{1}$, CHALID IDHAM ABDULLAH ${ }^{1}$, DANNY HILMAN \\ NATAWIDJAJA ${ }^{2}$.
}

1. Program Studi Teknik Geologi, Fakultas Ilmu dan Teknologi Kebumian, Institut Teknologi

Bandung (ITB), Jl. Ganesha No.10, Bandung, Jawa Barat, Indonesia, 40132, Email: indrajati85@gmail.com

2. Pusat Peneltian Geoteknologi, LIPI (Lembaga Ilmu Pengetahuan Indonesia)

\begin{abstract}
Sari - Zona Sesar Cimandiri dapat dilihat dari data citra satelit berupa kelurusan punggungan dan lembah dari teluk Pelabuhanratu, Kabupaten Sukabumi hingga Padalarang, Kabupaten Bandung. Sesar Cimandiri merupakan sesar aktif, yang ditandai dengan hadirnya gempabumi dangkal di sekitar sesar dan terjadi pergerakan horizontal berdasarkan pengamatan menggunakan metode Global Positioning System. Gempabumi yang terjadi jarang melebihi magnitudo $6 \mathrm{Mw}$ sehingga morfologi sesar tidak terlalu terlihat dan jalur sesar aktif sulit didentifikasi. Perhitungan channel stepness index merupakan salah satu metode untuk mengenali sesar aktif dari profil sungai. Profil sungai yang dianalisa di sepanjang zona Sesar Cimandiri menunjukkan nilai $\mathrm{k}_{\mathrm{sn}}>100 \mathrm{~m}^{0.9}$ merupakan nilai pada zona sesar aktif. Jalur sesar yang diperoleh adalah segmen Mekarasih, Cibatu, Tanjungsari dan Gandasoli. Jalur sesar diperoleh dari kompilasi data distribusi nilai channel stepness index, sejarah gempa, data seismisitas dan morfologi.
\end{abstract}

Kata kunci: Sesar Cimandiri, sesar aktif, channel stepness index.

\begin{abstract}
Cimandiri Fault Zone based on satelite image are hill and valley lineament from Pelabuhanratu bay, Sukabumi District to Padalarang, Bandung District. Cimandiri is active fault, based on shallow depth earthquake around fault and horizontal movement from GPS measurement. The earthquake rarely up to magnitude $6 \mathrm{Mw}$, so fault trace is hard to identified. Channel stepness index can be use to identifed active fault from river profile. River profile along Cimandiri Fault show that $k_{s n}>100 \mathrm{~m}^{0.9}$ are active fault. Fault trace can be identified from distribution of channel stepness index, earthquake history, seismicity data, and morphology. There are four segmen can be identified, which is Mekarasih, Cibatu, Tanjungsari and Gandasoli.
\end{abstract}

Keywords: Cimandiri fault, active fault, channel stepness index.

\section{Pendahuluan}

Sesar Cimandiri merupakan sesar yang terbentang dari teluk Pelabuhanratu melewati Sukabumi dan Cianjur hingga Padalarang (Gambar 1). Zona sesar terlihat karena adanya kelurusan lembah dan pegunungan, panjang sesar ini diperkirakan mencapai $100 \mathrm{~km}$. Secara kegempaan dan data pergerakan dari GPS (Abidin, 2009), data seismisitas dan sejarah gempa bumi di sekitar zona Sesar Cimandiri secara umum menunjukkan bahwa daerah ini dipengaruhi oleh aktifitas sesar (Gambar 2).

Secara administratif, daerah penelitian terletak di Kabupaten Sukabumi, Propinsi Jawa Barat. Memanjang dari teluk Pelabuhanratu di bagian barat hingga Kota Sukabumi di bagian timur. 


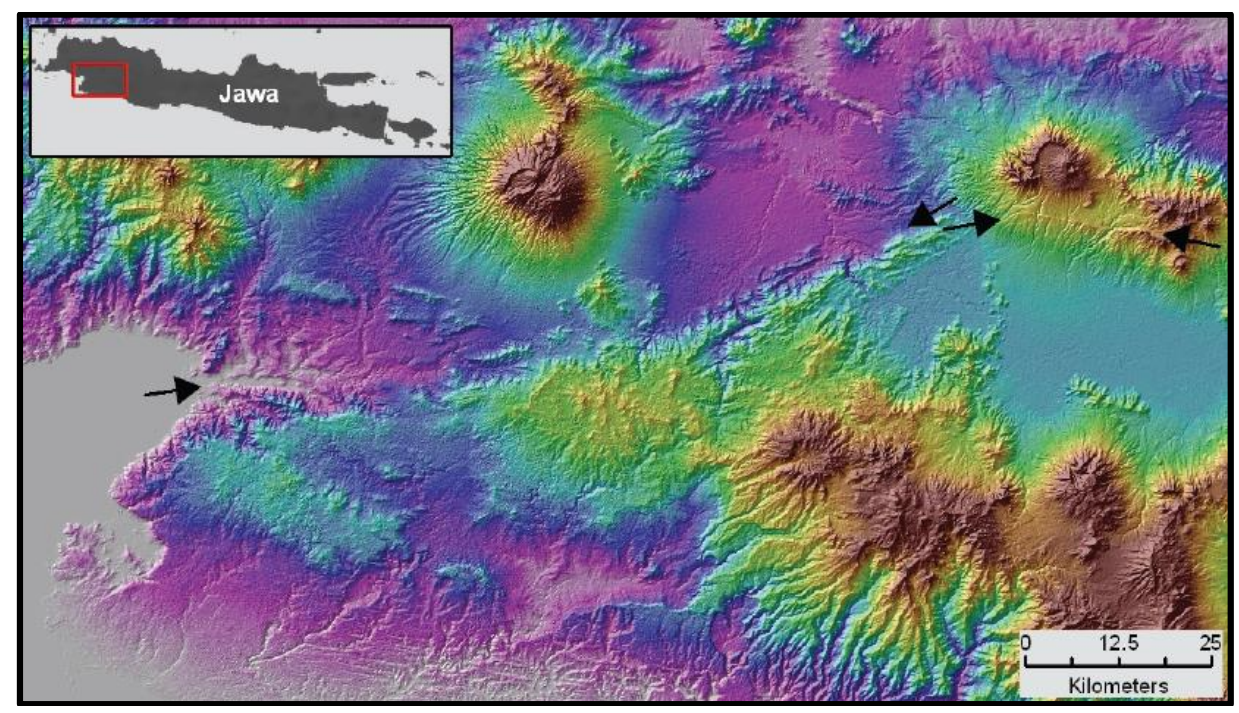

Gambar 1. Citra SRTM dari Pelabuhanratu hingga Bandung. Panah hitam menunjukkan kelurusan perbukitan dan lembah sebagai penciri zona Sesar Cimandiri dan Sesar Lembang (Horspool dkk., 2011).

\section{Tektonik Regional}

Struktur geologi regional daerah penelitian dipengaruhi oleh aktivitas tektonik akibat interaksi pergerakan lempeng Indo Australia dan Eurasia. Lempeng Indo Australia bergerak ke arah utara dan menghasilkan tumbukan lempeng sebagai hasil dari interaksi lempeng. Tumbukan lempeng ini menghasilkan jalur subduksi, gempabumi, prisma akresi, cekungan muka, jalur gunungapi dan pola struktur geologi yang tersebar di sekitarnya.

Jalur subduksi dari bagian barat pulau Sumatra, selatan Jawa tidak terputus hingga Nusa Tenggara namun kemunculan gunungapi di bagian utara jalur terletak terpisah. Menurut Haryanto (2014), hal ini mengindikasikan hadirnya celah/ jalur sesar yang mengontrol sebaran aktifitas vulkanik sebagai jalur keluarnya magma ke permukaan. Di Pulau Sumatra, kemunculan gunungapi aktif dan gempabumi berada di dalam dan disekitar zona Sesar Sumatera, yang merupakan sistem sesar utama. Pulau Jawa tidak memiliki satu sistem sesar utama, hanya memiliki beberapa sesar yang lebih kecil, seperti Sesar Cimandiri, Baribis, dan Lembang (Natawidjaja, 2016).

Beberapa penulis menyebutkan bahwa Sesar Cimandiri hanya pada lembah sungai Cimandiri yang membentang dari Pelabuhanratu hingga Kota Sukabumi (Dardji dkk., 1994, Supartoyo, 2014). Kelurusan ini juga menerus ke arah lepas pantai di baratdaya dari Teluk Pelabuhanratu hingga bertemu dengan Ujung Kulon fault zone, kelurusan ini dikenal dengan Pelabuhanratu fault zone (Malod dkk., 1995). Menurut Susilohadi dkk. (2009), Sesar Cimandiri pada bagian Pelabuhanratu terpecah menjadi beberapa sesar dan mengakomodasi gaya ekstensional sejak Miosen Akhir. Menurut Hall (1997) dan Haryanto (2014) Sesar Cimandiri terbentuk pada Plio - Plistosen dan merupakan satu rangkaian dengan Sesar Baribis di utaranya dan membentuk sesar naik dan pola struktur lipatan anjakan. 


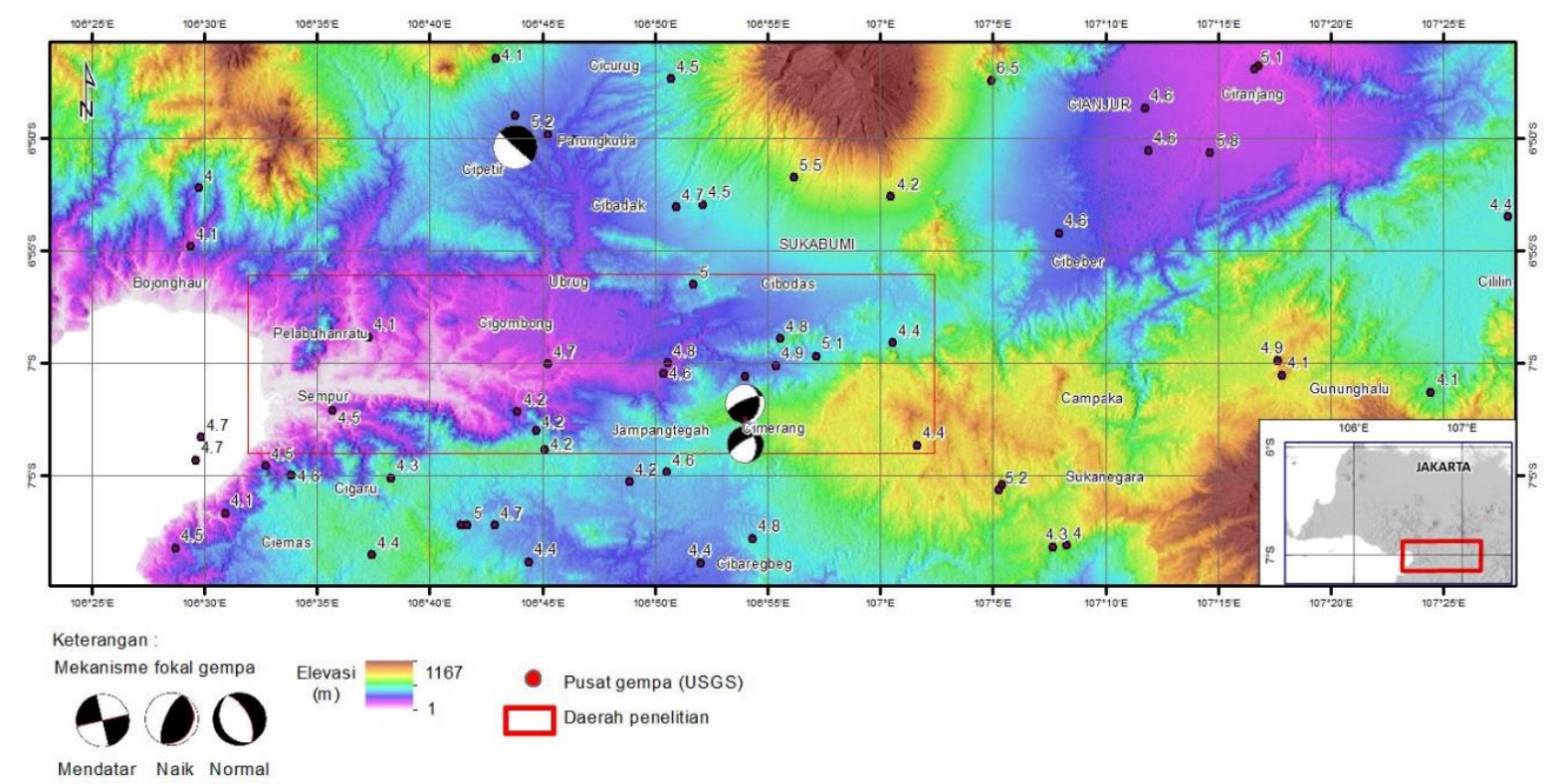

Gambar 2. Peta sebaran gempabumi dan mekanisme fokal daerah penelitian.

\section{Stratigrafi Regional}

Daerah sekitar zona sesar Cimandiri terbagi menjadi empat lembar peta geologi, yaitu Bogor (Effendi dkk., 1998), Sindangbarang dan Bandarwaru (Koesmono dkk., 1996), Jampang dan Balekambang (Sukamto, 1975) dan Cianjur (Sudjatmiko, 1972). Sebagian besar batuan tertutup oleh produk vulkanik resen. Endapan vulkanik ini menutup batuan sedimen fluvial dan laut dangkal berumur Eosen - Oligosen, dan batuan vulkanik dan turbidit berumur Miosen Pliosen.

\section{Sejarah Gempabumi}

Visser (1922) telah mendata gempabumi di Sumatra dan Jawa, sebaran gempabumi di Pulau Jawa. Gempa di sekitar Sesar Cimandiri terjadi pada tanggal 23 Maret 1879, gempa ini mengakibatkan hampir semua bangunan di Cianjur hancur dan kerusakan juga terjadi di Kota Sukabumi dan Bogor (Nat Tijdschr, 1882 dalam Visser, 1922). Gempa selanjutnya terjadi pada tanggal 14 Januari 1900 yang terjadi di Kota Sukabumi dan terasa di seluruh
Jawa bagian barat. Akibat gempa ini, terjadi kerusakan besar di Kota Sukabumi dan sekitarnya dan muncul rekahan dari Karang Tengah hingga Cibeber, Gunung Gede juga dilaporkan meningkat aktifitasnya setelah gempa terjadi (Nat. Tijdschr, 1902 dalam Visser, 1922).

Data sejarah kejadian gempabumi merusak tercatat sebanyak 13 kejadian di Kabupaten Sukabumi sejak tahun 1900 hingga 2008. Sebagian besar kejadian gempabumi merusak tersebut pusat gempabuminya terletak di darat dan berkaitan dengan pergerakan sesar aktif. Kejadian gempabumi tanggal 23 Juli 1962 telah mengakibatkan kerusakan sejumlah bangunan di daerah Citarik. Gempabumi tanggal 9 Februari 1975 dan 12 Juli 2000 yang mengalami kerusakan bangunan di daerah Cibadak. Kejadian gempabumi tanggal 10 Februari 1982 telah mengakibatkan kerusakan sejumlah bangunan di sepanjang lembah Cimandiri Kejadian gempabumi tersebut diperkirakan berasosiasi dengan Sesar Cimandiri (Supartoyo dan Surono, 2009). 


\section{Data dan Metode}

\subsection{Data}

Data yang digunakan dalam penelitian ini ada data Ifsar dan data SRTM. Data Ifsar yang digunakan merupakan data model elevasi digital dengan resolusi 5 meter. Data SRTM juga merupakan data model elevasi digital dengan resolusi 30 meter, data ini digunakan sebagai pelengkap dalam analisis.

\subsection{Metode}

\subsubsection{Sesar Aktif}

Dalam studi sesar aktif, sesar aktif didefinisikan sebagai sesar yang kemungkinan akan bergerak dan menghasilkan gempabumi. Menurut USGS, sesar dikategorikan aktif jika telah bergerak sekali atau beberapa kali dalam kurun waktu 10.000 tahun. Dalam pergerakan sesar, sering dijumpai segmentasi. Definisi segmentasi menurut USGS adalah pecahan atau bagian yang lebih kecil dari suatu sesar, yang merupakan hasil dari sesar lain yang memotong, perubahan topografi, atau terjadi pembelokan arah sesar. Jika terjadi gempabumi, segmentasi membatasi pergerakan sesar menjadi beberapa bagian sehingga kekuatannya menjadi terbatas.

Perubahan bentang alam merupakan respon dari perubahan tektonik dan iklim. Istilah knickpoint sering digunakan untuk titik perubahan gradien sungai, biasanya terdapat pada air terjun. Knickpoint dapat terbentuk pada batas perubahan litologi akibat perubahan kekuatan batuan, atau karena adanya gangguan akibat tektonik (Whittaker dan Boulton, 2012). Secara teori, model, dan observasi yang telah dilakukan oleh Tucker dan Whipple (2002) menunjukkan bahwa semua sungai yang semula dalam kondisi stabil akan berubah ketika terjadi perubahan laju tektonik, membentuk knickpoint yang curam dan beradaptasi dengan perubahan tersebut. Knickpoint yang terbentuk merupakan batas antara bagian sungai yang telah terubah akibat tektonik dan bagian sungai yang belum mengalami perubahan (Whittaker dan Boulton, 2012).

Dengan mempelajari sebaran dari knickpoint maka akan diperoleh daerah yang potensial mengalami perbedaan pengangkatan batuan dan kemungkinan merupakan sesar aktif (Whipple, 2013). Analisis ini mempunyai dasar teori dan didukung dengan hasil empirik yang menunjukkan bahwa hubungan antara kondisi stabil arus sungai dengan erosi memiliki jangka waktu 10 - 100 ribu tahun. (Whipple dan Tucker, 1999; Cyr dkk., 2010 dalam Marliyani, 2016).

\subsubsection{Perhitungan Channel Stepness Index}

Analisis indeks kecuraman sungai (channel stepness indeks/ $\mathrm{k}_{\mathrm{sn}}$ ) bertujuan untuk mencari sebaran kontras resistansi litologi dan pengangkatan relatif pada dasar sungai di sepanjang sesar Cimandiri. Indeks kecuraman sungai juga dapat dipakai untuk penentuan daerah yang berpotensi terdapat 6 sesar aktif dan lokasi knickpoint. Data digabungkan dengan data litologi dan struktur regional untuk mengidentifikasi daerah yang memiliki indikasi mengalami sesar aktif. Kajian bentuk lahan dan analisis knickpoint dilakukan pada data model elevasi digital.

Profil sungai dapat digunakan sebagai alat bantu untuk mengetahui keaktifan tektonik suatu wilayah. Profil sungai awalnya dikenalkan oleh Hack (1973, dalam Marliyani 2016), setelah diketahui hubungan antara gradien lereng lokal dan daerah aliran sungai adalah power law, kemudian dikenal sebagai hukum Flint (1974, dalam Marliyani 2016), sebagai :

$\mathrm{S}=\mathrm{k}_{\mathrm{S}} \mathrm{A}^{-\theta}$ 
Dengan S adalah local channel gradient, A adalah upstream drainage area, $\mathrm{k}_{\mathrm{s}}$ adalah channel stepness index, dan $\theta$ adalah concavity index (Gambar 3). Perhitungan pada profil sungai menggunakan persamaan dari Whipple (2013), yaitu:

$\mathrm{S}=\mathrm{k}_{\mathrm{sn}} \mathrm{A}^{-\theta r e f}$

\section{A Equilibrium Profiles: Concavity Index}

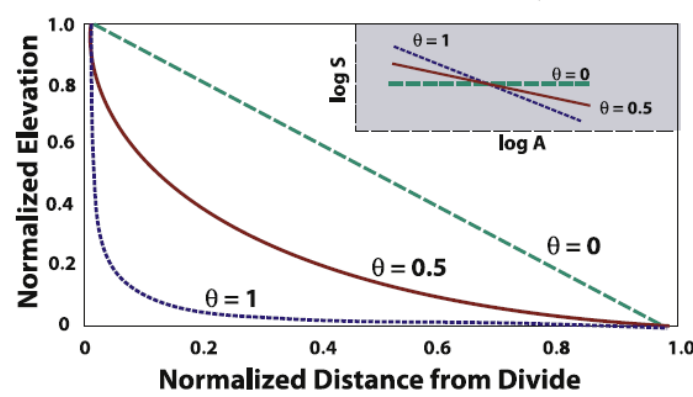

B Equilibrium Profiles: Steepness Index

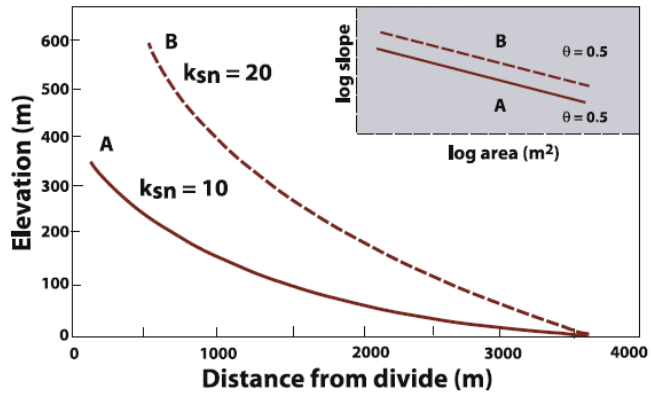

Gambar 3. Grafik yang menunjukkan perbedaan nilai parameter dalam perhitungan channel stepnees index. (A) menunjukkan perbedaan kecekungan akibat perubahan nilai $\theta$. (B) menunjukkan perbedaan tingkat kecuraman akibat perbedaan nilai $\mathrm{k}_{\mathrm{sn}}$ (Kirby dan Whipple, 2012).

Nilai $\theta_{\text {ref }}$ menurut Marliyani (2016) tidak berpengaruh besar terhadap hasil perhitungan, sehingga nilai $\theta_{\text {ref }}$ yang dipakai adalah 0.45 , disamakan dengan hasil penelitian yang lain (Marliyani, 2016; Wobus 2006). Nilai $\mathrm{k}_{\mathrm{sn}}$ yang dipakai adalah $\mathrm{m}^{0.9}$ untuk $\theta_{\text {ref }}=0.45$, didapat dari nilai referensi dari kecekungan (Wobus, 2006). Berdasarkan banyak penelitian, tingkat kecuraman $\mathrm{k}_{\mathrm{sn}}$ berhubungan dengan adanya akitiftas pengangkatan dan pengaruh litologi.

\section{Hasil}

Sebanyak 327 aliran sungai yang dianalisis menggunakan perhitungan indeks kecuraman sungai (Gambar 4). Panjang sungai terpendek dari hulu ke hilir adalah $2.8 \mathrm{~km}$ dan terpanjang $75 \mathrm{~km}$. Pehitungan dimulai dari hulu hingga hilir sungai yang dimulai dengan penentuan hulu sungai yang akan dihitung nilai $\mathrm{k}_{\mathrm{sn}}$. Posisi hulu sungai dan nilai parameter kemudian akan dihitung dengan menggunakan perangkat lunak dan dijadikan dalam bentuk grafik. Nilai $k_{s n}$ (indeks kecuraman sungai ternormalisasi) diperoleh dari hasil interpretasi posisi knickpoint pada grafik log gradient vs jarak (Gambar 5).

Hasil perhitungan $\mathrm{k}_{\mathrm{sn}}$ di aliran sungai peroleh nilai dari indeks 1 hingga $280 \mathrm{~m}^{0.9}$, nilai tersebut kemudian dikelompokkan menjadi empat kelompok (Gambar 6). Pengelompokkan mengacu pada Marliyani (2016) yang membagi nilai $\mathrm{k}_{\mathrm{sn}}$ menjadi empat kelompok pada daerah dengan aktifitas pergerakan sesar yang lambat. Kelompok tersebut adalah:

1. Nilai $k_{s n} 1-60 m^{0.9}$, kelompok ini umum terdapat pada bagian sungai besar atau pada hulu sungai dengan daerah yang landai.

2. Nilai $\mathrm{k}_{\mathrm{sn}} 60-80 \mathrm{~m}^{0.9}$, kelompok ini merupakan bagian yang agak landai pada profil sungai. Bagian ini merupakan bagian yang mendekati kelompok 1, umum terdapat pada sungai yang berada di tengah pegunungan.

3. Nilai $\mathrm{k}_{\mathrm{sn}} 80-100 \mathrm{~m}^{0.9}$, kelompok ini merupakan bagian agak terjal dari profil sungai. Bagian ini biasa berdekatan dengan kelompok 4, dan di interpretasikan merupakan kemenerusan dari sesar aktif. 
4. Nilai $\mathrm{k}_{\mathrm{sn}}>100 \mathrm{~m}^{0.9}$, kelompok ini merupakan bagian terjal dari profil sungai. Sesar kemungkinan berada pada daerah sekitar kelompok ini. Atau akibat adanya kontras litologi yang mendadak pada alur sungai.

Nilai $\mathrm{k}_{\mathrm{sn}}>60 \mathrm{~m}^{0.9}$ terindikasi sesar aktif, kemudian dikelompokkan dalam zona untuk mengetahui kemenerusan sesar aktif yang terindikasi dari nilai $\mathrm{k}_{\mathrm{sn}}$. Terdapat tujuh zona berdasarkan kemenerusan nilai $\mathrm{k}_{\mathrm{sn}}$ secara lateral yang akan di tumpang susun dengan sesar aktif hasil pemetaan morfologi sesar aktif untuk memverifikasi nilai indeks kecuraman sungai.

Setelah dilakukan perhitungan, maka perlu dilakukan pengelompokkan nilai $\mathrm{k}_{\mathrm{sn}}$ secara spasial. Zonasi didasarkan pada distribusi nilai $\mathrm{k}_{\mathrm{sn}}$, yaitu pada daerah yang memiliki kemungkinan terdapat sesar aktif (Gambar 7). Nilai $\mathrm{k}_{\mathrm{sn}}>60 \mathrm{~m}^{0.9}$ dianggap bisa mengidentifikasi sesar aktif. Penarikan jalur sesar pada zona ini dapat dibantu dengan morfologi yang diperoleh dari data model elevasi digital. Pembagian zona kemungkinan sesar adalah sebagai berikut:

1. Zona 1, terdapat di daerah Cibuntu. Kisaran nilai $\mathrm{k}_{\mathrm{sn}}$ adalah $61-114 \mathrm{~m}^{0.9}$

2. Zona 2, terdapat di daerah Langkarjaya. Kisaran nilai $\mathrm{k}_{\mathrm{sn}}$ adalah $61-168 \mathrm{~m}^{0.9}$

3. Zona 3, terdapat di daerah Mekarasih. Kisaran nilai $\mathrm{k}_{\mathrm{sn}}$ adalah $66-139 \mathrm{~m}^{0.9}$

4. Zona 4, terdapat di daerah Cibatu. Kisaran nilai $\mathrm{k}_{\mathrm{sn}}$ adalah $77-99 \mathrm{~m}^{0.9}$

5. Zona 5, terdapat di daerah Jampang Tengah. Kisaran nilai $\mathrm{k}_{\mathrm{sn}}$ adalah $65-118$ $\mathrm{m}^{0.9}$

6. Zona 6, terdapat di daerah Tanjungsari. Kisaran nilai $\mathrm{k}_{\mathrm{sn}}$ adalah $61-139 \mathrm{~m}^{0.9}$

7. Zona 7, terdapat di daerah Gandasoli. Kisaran nilai $\mathrm{k}_{\mathrm{sn}}$ adalah $67-85 \mathrm{~m}^{0.9}$

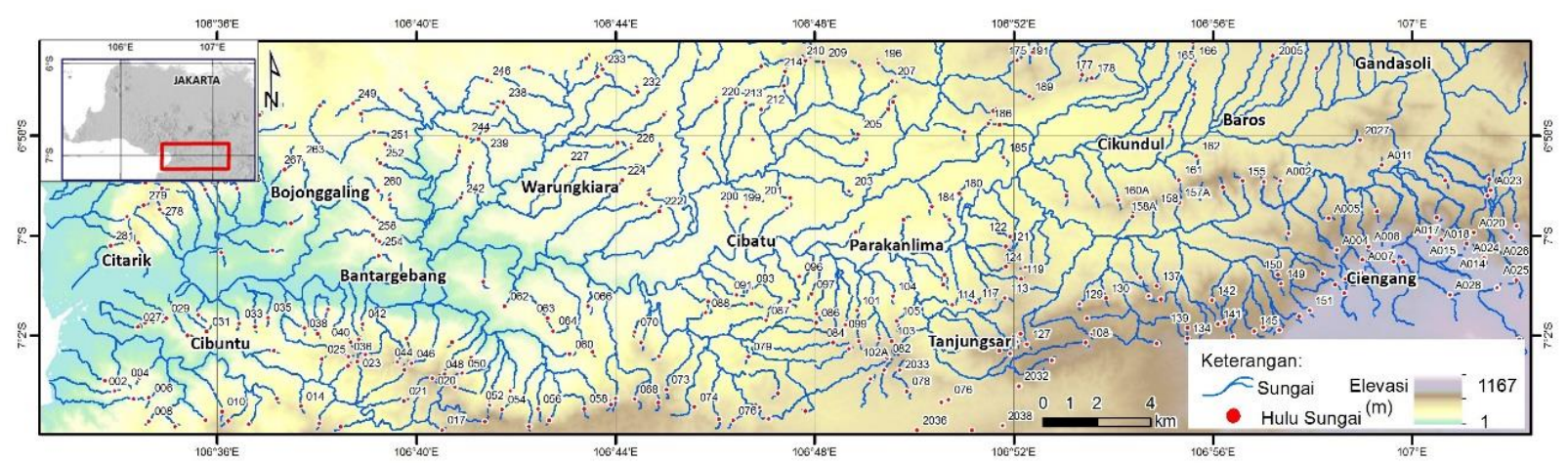

Gambar 4. Peta lokasi hulu sungai yang digunakan dalam perhitungan nilai indeks kecuraman sungai $\left(\mathrm{k}_{\mathrm{sn}}\right)$. 


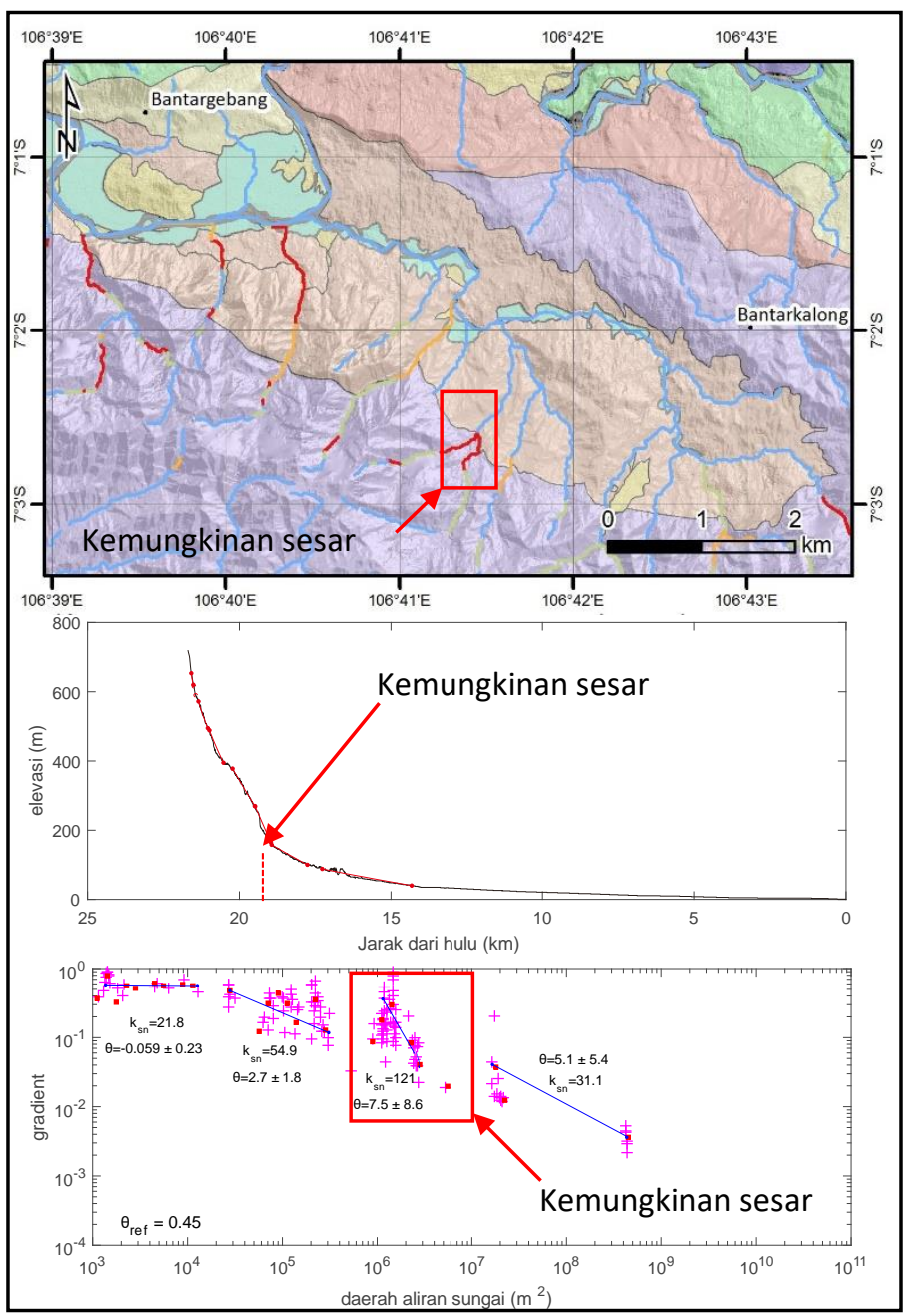

Gambar 5. Contoh perhitungan indeks kecuraman sungai pada peta, profil sungai, dan plot gradien $v s$ daerah aliran sungai. Kotak merah menunjukkan kemungkinan sesar aktif antara Formasi Jampang dan Formasi Rajamandala. Lokasi contoh secara regional terlihat pada Gambar 6.

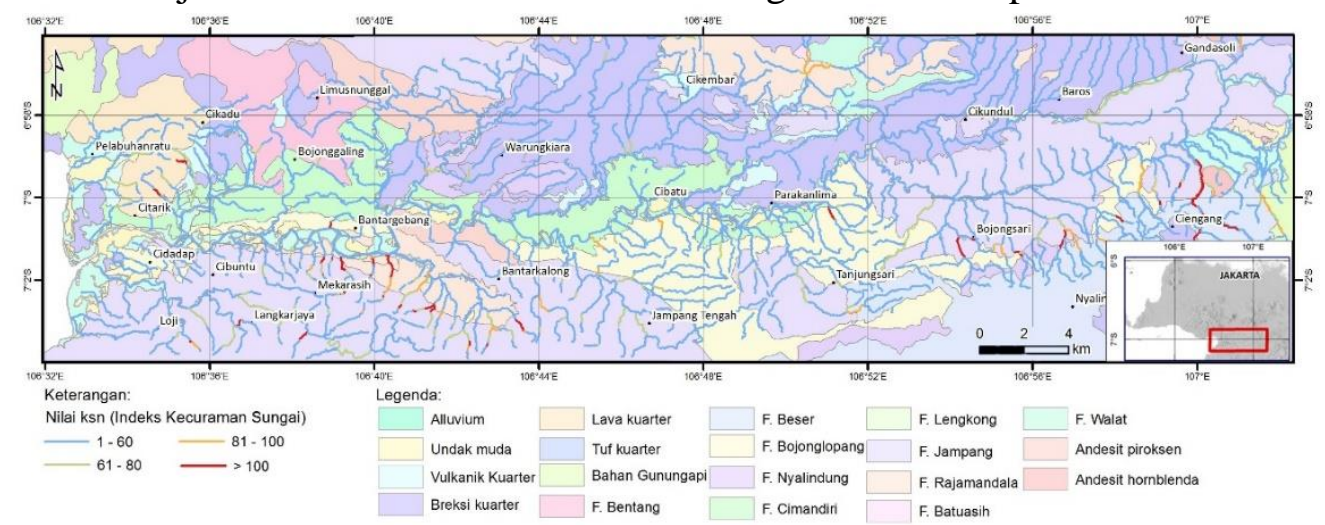

Gambar 6. Sebaran nilai $\mathrm{k}_{\mathrm{sn}}$ pada daerah penelitian. Panah merah menunjukkan nilai $\mathrm{k}_{\mathrm{sn}}$ tinggi berkorelasi dengan perbedaan formasi, yaitu lava kuarter dengan alluvium. Kotak biru merupakan lokasi contoh pada gambar 5. Peta geologi modifikasi dari Sudjatmiko (1972), Sukamto (1975), Koesmono dkk. (1996), dan Effendi dkk. (1998). 


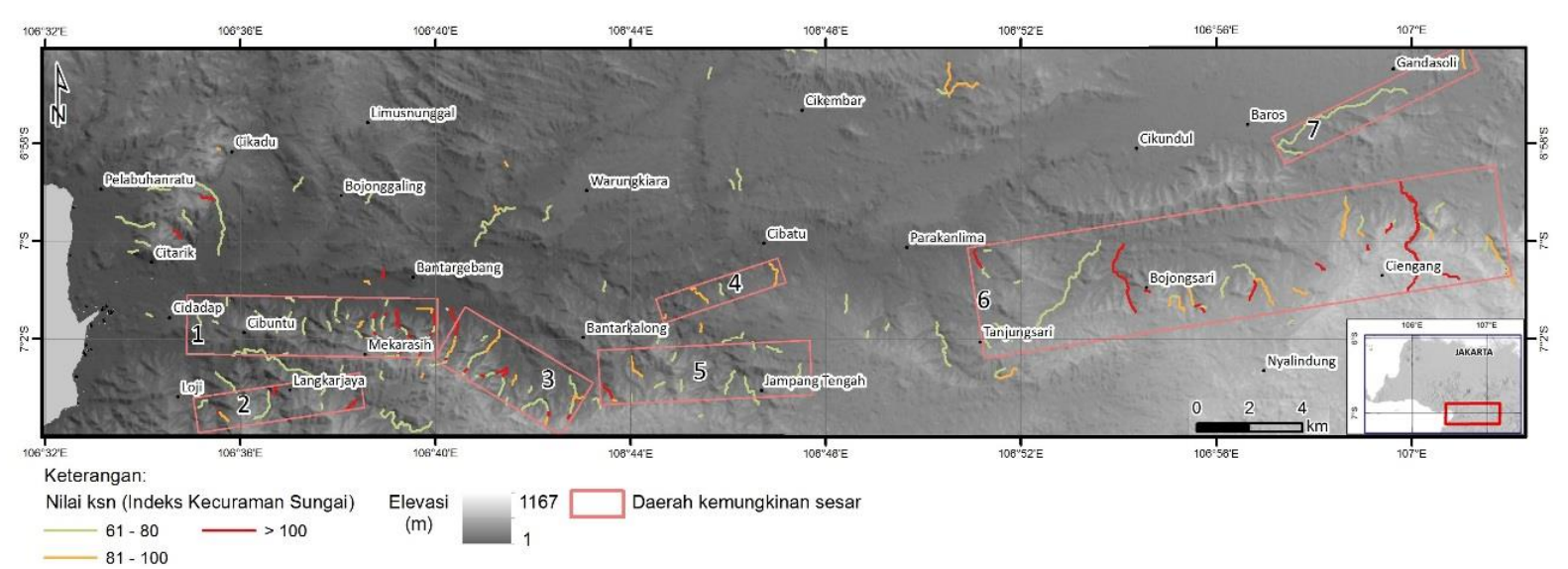

Gambar 7. Sebaran nilai $\mathrm{k}_{\mathrm{sn}}$ diatas $60 \mathrm{~m}^{0.9}$ yang menunjukkan zonasi yang berpotensi sebagai daerah sesar aktif. Terdapat tujuh zona yang diinterpretasi merupakan sesar aktif.

\section{Diskusi}

Berdasarkan hasil perhitungan morfometri, dengan menggunakan metode indeks kecuraman sungai dihasilkan tujuh zona yang berpotensi memiliki sesar aktif. Daerah dengan kemungkinan sesar aktif adalah pada daerah Cibuntu, Langkarjaya, Mekarasih, Cibatu, Bantarkalong, Tanjungsari dan Gandasoli. Proses validasi sesar aktif pada metode ini menggunakan data model elevasi digital untuk melihat kecocokan nilai $\mathrm{k}_{\mathrm{sn}}$ bentuk lahan akibat sesar.

Hasil analisis morfotektonik dan perhitungan morfometri kemudian digabung menjadi peta segmen Sesar Cimandiri yang aktif. Beberapa struktur yang tidak menerus juga muncul pada analisis morfotektonik, struktur tersebut dianggap sebagai struktur penyerta dari sesar utama. Struktur penyerta yang teridentifikasi dari morfotektonik adalah lipatan dan sesar mendatar sinistral. Tidak semua hasil perhitungan morfometri cocok dengan pengamatan morfotektonik sesar aktif. Perbedaan identifikasi ini terjadi karena pada pada sesar mendatar dan lipatan di daerah ini tidak mengalami perbedaan elevasi yang signifikan, sedangkan metode morfometri tidak mengenali struktur dengan elevasi yang relatif sama. Sebagian besar pengamatan morfotektonik sesuai dengan perhitungan morfometri, sehingga data morfometri bisa dijadikan data pendukung hadirnya sesar aktif di Sesar Cimandiri.

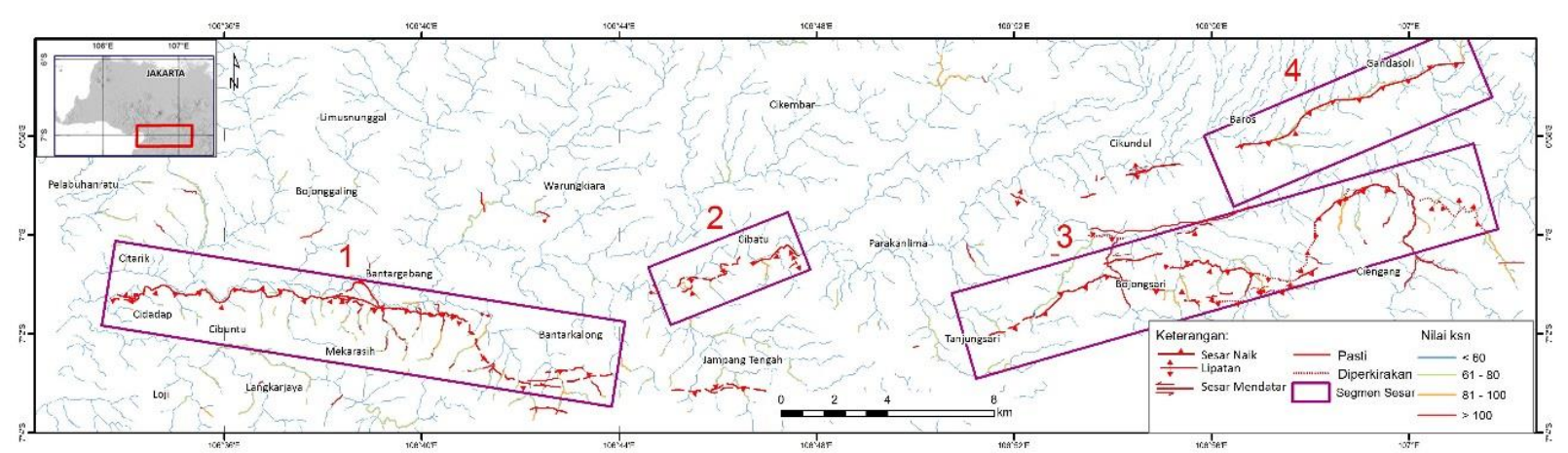

Gambar 8. Segmen Sesar Cimandiri dan nilai $\mathrm{k}_{\mathrm{sn}}$. 


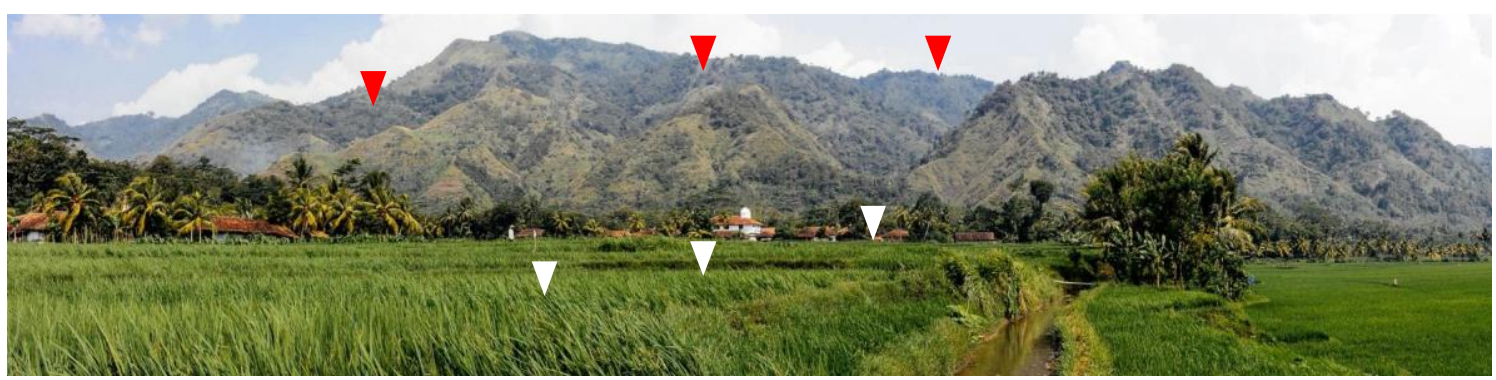

Gambar 9. Morfologi perbukitan dan teras pada bagian selatan sungai Cimandiri. Teras (segitiga putih) terlihat pada perbedaan ketinggian sawah. Pada latar belakang terlihat bentuk faset segitiga (segitiga merah) pada bagian muka perbukitan di daerah Mekarasih.

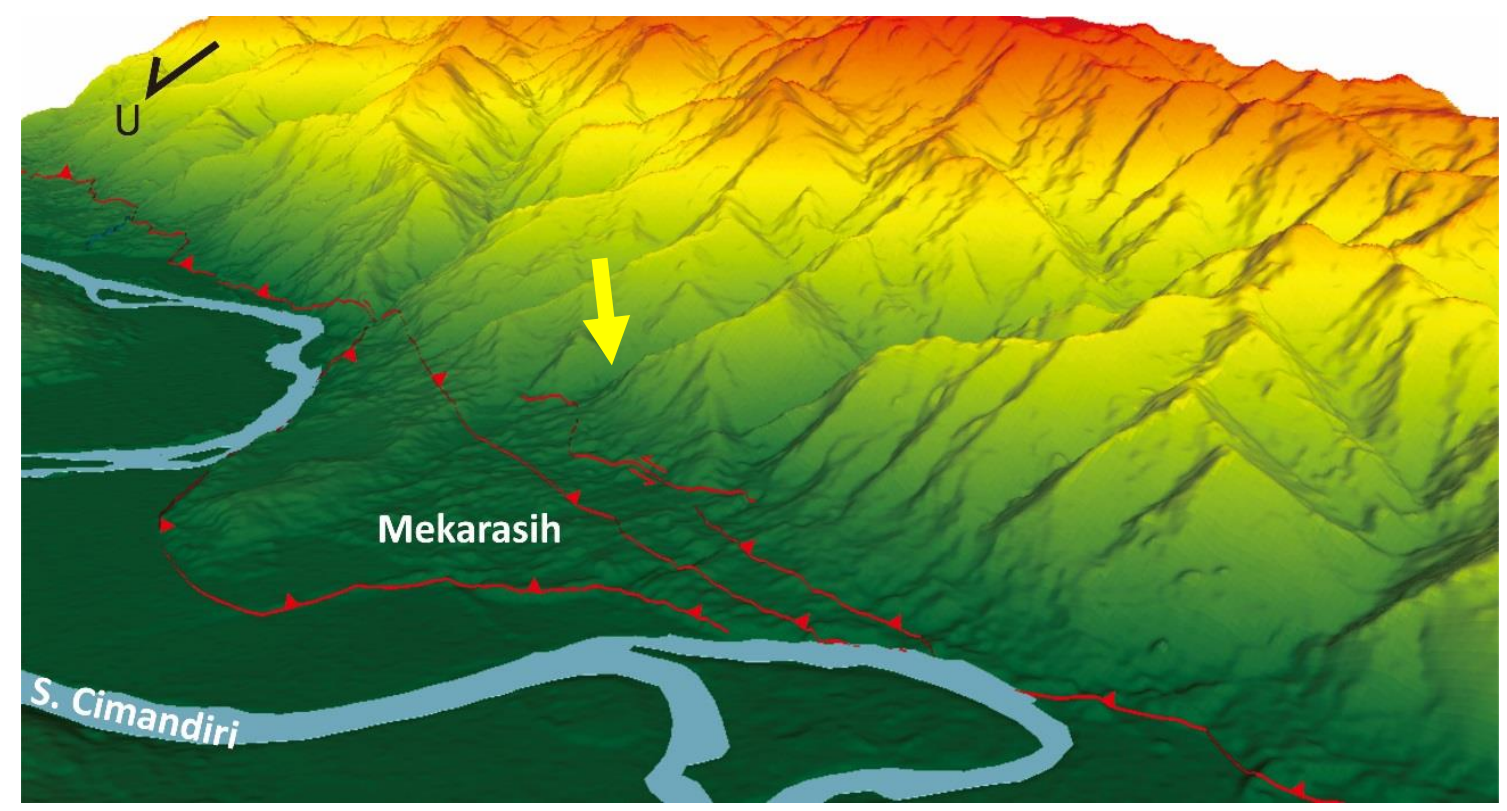

Gambar 10. Model tiga dimensi tanpa skala topografi daerah Mekarasih. Kipas alluvial yang terpotong sesar mendatar (panah kuning) terindikasi pada analisis morfotektonik, tapi tidak teridentifikasi dengan analisis morfometri.

Dari hasil analisis morfologi, perhitungan morfometri, sejarah gempa, dan data seismisitas, sehingga Sesar Cimandiri dapat dibagi menjadi beberapa segmen (Gambar 8). Segmen tersebut adalah:

\section{Segmen Mekarasih}

Menurut zona morfometri, segmen ini termasuk dalam zona Cibuntu hingga Jampang. Menurut pembagian morfotektonik Sesar Cimandiri, segmen ini merupakan bagian 1, 2, 3 dan 4. Segmen ini berupa sesar naik, dengan beberapa sesar sinistral minor. Morfotektonik yang terindentifikasi pada segmen ini adalah gawir sesar, faset segitiga (Gambar 9), teras yang terangkat, kipas alluvial yang terpotong (Gambar 10), pembelokan sungai, knickpoint, segitiga dan kehadiran mata air.

\section{Segmen Cibatu}

Menurut zona morfometri, segmen ini berada pada zona Cibatu dan menurut zona morfotektonik, segmen ini berada pada bagian 5. Segmen ini merupakan sesar 
naik, dengan beberapa sesar sinistral minor. Morfotektonik yang teridentifikasi pada segmen ini adalah gawir sesar, kipas alluvial yang terpotong, teras sungai yang terangkat, dan mata air.

\section{Segmen Tanjungsari}

Menurut zona morfometri, segmen ini berada pada zona Tanjungsari dan berdasarkan analisis morfotektonik, termasuk dalam bagian 6, 7, dan 8. Pada segmen ini sesar naik dominan, dengan sesar sinistral dan lipatan sebagai struktur minor. Morfotektonik yang teridentifikasi dari segmen ini adalah gawir sesar, teras yang terangkat, kipas alluvial yang terpotong, faset segitiga, pembelokan sungai, dan knickpoint. Sebagian dari segmen ini pernah terjadi aktifitas gempabumi. Berdasarkan data dari Global CMT pada tahun 10 September 1977 (5.7 $\mathrm{Mw})$ dan 12 Juli 2000 (5.3 Mw).

\section{Segmen Gandasoli}

Segmen Gandasoli tidak teridentifikasi secara morfotektonik dari data model elevasi digital resolusi 5 meter. Zona ini terindikasi menjadi sesar aktif karena memiliki nilai ksn $77-99 \mathrm{~m}^{0.9}$ dan pernah terjadi gempa pada tahun 1982 dengan magnitudo 5.3 Mw.

Beberapa zona pada analisis morfometri tidak terindikasi sebagai sesar karena nilai ksn tersebut tidak didukung dengan morfologi sesar aktif. Pada bagian zona Cibatu, sesar aktif digambarkan dalam bentuk diperkirakan, karena nilai ksn yang tidak mencapai $100 \mathrm{~m}^{0.9}$. Zona ini mengindikasikan bahwa secara morfometri daerah ini kurang aktif secara tektonik. Zona Langkarjaya memiliki nilai ksn 61 $168 \mathrm{~m}^{0.9}$, tetapi morfologi sesar aktif tidak dijumpai pada zona ini.

\section{Kesimpulan}

Perhitungan indeks kemiringan sungai dapat digunakan untuk mencari zona jalur sesar. Zonasi nilai $\mathrm{ksn}>100 \mathrm{~m}^{0.9}$ akan menunjukkan daerah dengan kemungkinan sesar aktif. Penentuan jalur sesar dengan rinci diperlukan validasi dengan analisis morfotektonik sesar aktif pada data model elevasi digital. Penentuan keaktifan sesar memerlukan penambahan data seismisitas. Untuk identifikasi bentuk lahan akibat gempabumi secara detail, diperlukan model elevasi digital dengan resolusi yang lebih besar

\section{DAFTAR PUSTAKA}

Abidin, H. Z., Andreas, H., Kato, T., Ito, T., Meilano, I., Kimata, F., Natawidjaja, D. H., dan Harjono, H. (2009): Crustal Deformation Studies in Java (Indonesia) using GPS. Jurnal of Earthquake and Tsunami, 3(2): 77-88.

Anonim, USGS (United States Geological Survey), Earthquake Glossary, http://earthquake.usgs.gov/learn/glossary. Diakses pada tanggal 1 Mei 2017.

Dardji N., Villemin, T., and Rampnoux, J. P. (1994): Paleostress and strikeslip movement: the Cimandiri Fault Zone, West Java, Indonesia. Journal of South East Asian Earth Sciences. 9, 1/2, 3-11.

Data Gempabumi periode 1964 - 2017 merupakan data dari United States Geological Survey, data diperoleh dari situs internet: http://earthquake.usgs.gov/earthqu akes/map. Diunduh pada tanggal 1 Mei 2017.

Effendi, A. C., Kusnama, dan Hermanto, B. (1998): Peta Geologi Lembar Bogor, Jawa (edisi kedua), Skala 1 : 100.000, Pusat Penelitian dan Pengembangan Geologi, Bandung.

Hall, R., Clements, B., Smyth, H. R., dan Cottam, M. A. (2007): A new interpretation of Java structure, Proceeding of 31st Annual 
Convention and Exhibition of Indonesian Petroleum Association.

Haryanto, I. (2014). Evolusi Tektonik Pulau Jawa Bagian Barat Selama Kurun Waktu Kenozoikum, Disertasi Doktor, Universitas Padjadjaran, Bandung (tidak dipublikasikan).

Horspool, N., Natawidjaja, D. H., Yulianto, E., Lawrie, S., dan Cummins, P. (2011): An Assessment on the use of High Resolution Digital Elevation Models for Mapping Active Faults in Indonesia, Natural Hazards Impact Project Risk and Impact Analysis Group Geoscience Australia.

Kirby, E., dan Whipple, K. X. (2012): Expression of active tectonics in erosional landscapes, Journal of Structural Geology, 44, 54-75.

Koesmono, M., dan Kusnama, S. N. (1996): Peta Geologi Lembar Sindang Barang dan Bandarwaru, Jawa. Skala 1: 100.000, Pusat Penelitian dan Pengembangan Geologi, Bandung.

Malod, J. A., Karta, K., Beslier, M. O., dan Zen, M. T. (1995): From Normal to Oblique Subduction: Tectonic Relationships between Java and Sumatera, Journal of Southeast Asian Earth Sciences, 12, No.12, $85-93$.

Marliyani, G.I., Arrowsmith, J.R., dan Whipple, K.X. (2016): Charaterization of slow slip rate fault in humid areas: Cimandiri fault zone, Indonesia, Journal of Geophysical Research: Earth Surface, 121, No.12, December 2016, 2287-2308.

Natawidjaja, D. H., Daryono, M. R. (2016): Present-Day Tectonics and
Earthquake History of Java, Indonesia, Proceedings Geosea XIV and 45th IAGI Annual Convention 2016, 365 - 374.

Soekamto (1975): Peta Geologi Lembar Jampang dan Balekambang, Jawa, Skala 1: 100.000, Pusat Penelitian dan Pengembangan Geologi, Bandung.

Sudjatmiko (1972): Peta Geologi Lembar Cianjur, Jawa, Skala 1: 100.000, Pusat Penelitian dan Pengembangan Geologi, Bandung.

Supartoyo, dan Surono (2009): Kegempaan di Wilayah Jawa Barat dan Kejadian Gempabumi Jawa Barat Selatan Tanggal 2 September 2009, Jurnal Gunungapi dan Mitigasi Bencana Geologi, 1, No.2 July 2009.

Supartoyo (2014): Geomorfologi Tektonik Sesar Cimandiri Daerah Sukabumi, Provinsi Jawa Barat, Disertasi Doktor, Institut Teknologi Bandung (tidak dipublikasikan).

Tucker, G. E., Whipple, K. X., (2002): Topographic outcomes predicted by stream erosion models: Sensitivity analysis and intermodel comparison, Journal of Geophysical Research, 107, No. B9, 2179 , doi:10.1029/2001JB000162.

Whipple, K. X., DiBiase, R. A., dan Crosby B. T. (2013): 9.28 Bedrock Rivers, In J. F.Shroder (Ed.), Treatise on Geomorphology (pp. 550-573), Academic Press, San Diego.

Whittaker, A. C., dan Boulton, S. J. (2012): Tectonic and climatic controls on knickpoint retreat rates and landscape response times, Journal of Geophysical Research, 117(F2), F02024. 
Wobus, C., Whipple, K. X., Kirby, E., Visser, S. W. (1922): Inland and Snyder, N., Johnson, J., Spyropolou, K., Crosby, B., dan Sheehan, D. (2006): Tectonics from topography: Procedures, promise, and pitfalls, in Tectonics, Climate, and Landscape Evolution, edited by S. D. Willett et al., Penrose Confference Ser., Spec. Paper Geol. Soc. Am., 398, 55-74. Submarine Epicentra of Sumatra and Java Earthquakes, Verhandelingen no. 9 (Complement to Ver Verhandelingen no. 7), Javasche Boekhandel En Drukkerij, Batavia, 7-13 